\title{
Effect of temperature and photoperiod on growth and reproductive development of goatsrue
}

\author{
DAVID T. PATTERSON
}

\author{
Author is plant physiologist, USDA-ARS, Botany Department, Duke University, Durham, N.C. 27706.
}

\begin{abstract}
Goatsrue (Galega officinalis L.) was introduced into northern Utah from Europe as a potential forage crop in 1891. Subsequent testing indicated goatsrue was unpalatable and toxic to livestock. The test plots were abandoned, and goatsrue escaped to become established as a weed. Goatsrue now is targeted for eradication under the Federal Noxious Weed Act, and information about its environmental requirements and potential for further range expansion in the United States is needed. In controlled environment chambers, plants were grown for 89 days in 4 day/night temperature regimes. Goatsrue produced $88,100,57$, and $86 \%$ of its maximum dry matter at $26 / 14,26 / 22,34 / 14$, and $34 / 22^{\circ} \mathrm{C}$, respectively. Dry matter production was closely correlated with leaf area duration. When 20-day-old plants were transferred from a 12-hour photoperiod to longer photoperiods, flower buds appeared after 20,26 , and 69 days in photoperiods of 18,16 , and 14 hours, respectively. Plants in these longer photoperiods subsequently nowered and produced fruit, but no reproductive development occurred after 130 days in the 12-hour photoperiod. Goatsrue is not well-adapted to the large diurnal variation in temperature typical of summer conditions in the Intermountain region of the United States. Temperature conditions in the Midwest or South would be more favorable to its growth.
\end{abstract}

\section{Key Words: Galega officinalis L., growth analysis, weed infestation}

Goatsrue (Galega officinalis $\mathrm{L}$.) is a perennial legume native to Europe and western Asia (Barneby 1989, Tutin et al. 1976, Evans and Ashcroft 1982). It resembles alfalfa (Medicago sativa L.) in growth habitat. Goatsrue was introduced into the United States in 1891 at Logan, Utah, for evaluation as a potential forage plant (Tingey 1971, Evans 1984). Subsequently, it was found to be unpalatable to livestock. Goatsrue is now known to contain a toxic alkaloid, galegine, which is harmful to sheep and cattle (Williams 1980).

When the undesirable characteristics of goatsrue were recognized, experimental plants in the field trials were abandoned. The species apparently spread from the original experimental plantings and now infests approximately 15,000 ha of Cache County, Utah (Evans 1984). Goatsrue occurs mainly in noncropland areas, but it also may invade established alfalfa stands (Evans 1984). Its presence as a contaminant of alfalfa harvested for forage may render the alfalfa unpalatable.

Goatsrue is 1 of 93 taxa classified as Federal Noxious Weeds under the Federal Noxious Weed Act of 1974 (Westbrooks 1989). As such, it is 1 of several species targeted for containment and eradication by the U.S. Department of Agriculture's Animal and Plant Health Inspection Service (APHIS). Thus it is desirable to determine the potential for further geographic expansion by goatsrue. Based on its world distribution, the species as a whole appears to have a wide ecological amplitude. In Europe and west-

Partial support for controlled environment space was provided by National Science Foundation Grant BSR 87-06429 to the Duke University Phytotron.

Manuscript accepted 18 Jan. 1992. ern Asia where it is native, goatsrue occurs from Spain and Great Britain east to Iran and north to Scandinavia (Tutin et al. 1976, Barneby 1989). Introduced populations occur in Argentina, Chile, Ecuador, and New Zealand as well as in the United States (Holm et al. 1979). Unfortunately, the native origin of the genotype introduced into the United States is unknown. It seems likely that the present infestations resulted from a single introduction at the Utah Agricultural Experiment Station in Logan, but this has been questioned (Tingey 1971). The present study examined the effects of temperature and photoperiod on vegetative growth and reproductive development of goatsrue in an unlimited soil moisture environment.

\section{Materials and Methods}

\section{Plant Material and Experimental Conditions}

Experiments were conducted in the Duke University Phytotron, a limited access, controlled-environment facility. The use of such a facility minimized the risk of further accidental spread of goatsrue that would accompany widespread experimental field plantings otherwise necessary to establish its response to environmental factors (Patterson 1983).

Seeds of goatsrue were obtained from field plants in Cache County, Utah. The seeds were scarified in concentrated $\mathrm{H}_{2} \mathrm{SO}_{4}$ for 30 min to make the seed coat permeable and allow imbibition and germination to proceed. Scarified seeds were germinated in 9-cm petri dishes on moist filter paper in 4 temperature regimes. Eleven dishes containing 25 seeds each were placed in each regime. The 4 regimes were provided in 2 controlled-environment chambers programmed for day/night temperatures of $26 / 14$ and $34 / 22^{\circ} \mathrm{C}$. Day/night regimes of $26 / 22$ and $34 / 14^{\circ} \mathrm{C}$ were provided by moving carts containing the petri dishes from 1 chamber to another daily at 0830 and 1630 hours. The day temperatures were programmed from 0830 to 1630 hours. Day time relative humidities were adjusted to $70 \%$ at $26^{\circ} \mathrm{C}$ or $80 \%$ at $34^{\circ} \mathrm{C}$ to provide equal vapor pressure deficits of $10 \mathrm{mb}$ in the 2 chambers. The chambers were illuminated with a mixture of sodium vapor and metal halide lamps. During seed germination, the petri dishes were protected by shading, and the number of lamps was reduced to prevent heating of the petri dishes above ambient air temperature in the chambers. The photosynthetic photon flux density at the level of the petri dishes was $50 \mu \mathrm{mol} \mathrm{m} \mathrm{m}^{-2} \mathrm{~s}^{-1}$. The photoperiod was 12 hours, from 0630 to 1830 hours. After germination, 3-day-old seedlings were transplanted to $7-\mathrm{cm}$-diameter plastic pots containing $350 \mathrm{~cm}^{3}$ of a 1:1 mixture of coarse vermiculite and grade 16 gravel. For 5 days, the photosynthetic photon flux density was maintained at 300 $\mu \mathrm{mol} \mathrm{m}^{-2} \mathrm{~s}^{-1}$ to reduce the radiant heat load during seedling establishment. Subsequently the photosynthetic photon flux density was increased to $1,000 \mu \mathrm{mol} \mathrm{m}^{-2} \mathrm{~s}^{-1}$ for the duration of the experiment. The 2 growth chambers used in this experiment were identical units (EGC' model M-12) located adjacent to each other in the Duke University Phytotron. Temperatures in both chambers were continually monitored and maintained within $\pm 1^{\circ} \mathrm{C}$ of the setpoint. 
Plants were maintained in the 4 temperature regimes for 89 days after germination and emergence. To avoid limiting root volume, plants were transplanted twice, first to $900 \mathrm{~cm}^{3}$ pots at $28 \mathrm{DAE}$ and finally to $3,500 \mathrm{~cm}^{3}$ pots at 60 days after emergence. Pots were watered to excess twice daily, with half-strength Hoagland's Solution (Downs and Hellmers 1975) in the morning and demineralized water in the afternoon. Therefore, soil moisture did not limit growth

To determine the effects of photoperiod on reproductive development, five 20-day-old seedlings were transferred from each of the 4 temperature regimes to each of 4 identical growth chambers (EGCl) model 12), programmed for $26 / 22^{\circ} \mathrm{C}$ day/night and photoperiods of $12,14,16$, or 18 hours. These chambers were illuminated with a mixture of fluorescent and incandescent lamps providing an 11 -hour core period of $350 \mu \mathrm{mol} \mathrm{m}^{-2} \mathrm{~s}^{-1}$ with appropriate $\mathrm{AM}$ and $\mathrm{PM}$ extensions of the core period with incandescent lamp only at $50 \mu \mathrm{mol} \mathrm{m}^{-2} \mathrm{~s}^{-1}$ to give the desired total photoperiods of 12 , 14,16 , and 18 hours. The plants were maintained in the 4 photoperiod treatments for 130 days.

\section{Harvest Procedures and Data Collection}

Germination counts were taken at 1,2 , and 3 days after the seeds were placed in the petri dishes. An initial harvest was obtained at the time of transplanting of the emerged seedlings to determine cotyledon area and plant dry weight. Transplanted seedlings were harvested at 7- or 14-day intervals beginning at 14 days after transplanting. Seven replicate plants were harvested each time for determination of plant height, numbers of stems and leaves, leaf area, and dry weight of leaves, stem, and roots.

The plants transferred to the 4 photoperiod treatments were monitored for first appearance of flower buds and flowers. Selected flowers were "tripped" by manipulating the keel petals with a toothpick to free the staminal tube, rupture the stigmatic membrane, and enable self-pollination to occur, as described by Barnes et al. (1972) for alfalfa. For security reasons, fruits were harvested before mature seeds were produced.

\section{Data Analysis}

Data collected at the final harvest were subjected to analysis of variance to determine temperature effects on plant height, numbers of stems and leaves, leaf area, and leaf, stem, root, and total plant dry weights. Temperature effects on biomass partitioning were examined by calculating leaf, stem, and root weight ratios by dividing the dry weight of the respective plant part by the total plant dry weight. The specific leaf area and leaf area ratio also were calculated as leaf area/leaf dry weight and leaf area/total plant dry weight, respectively. Data were subjected to analysis of variance, with Duncan's multiple range test used for means separation.

In order to verify that biomass partitioning values from the final harvest reflected trends during the whole period of growth, allometric regression equations were calculated to relate leaf, stem, or root weight to total plant weight, leaf area to leaf weight, and leaf area to total plant weight. These equations were calculated from data from individual replicate plants from all harvests.

Mathematical growth analysis techniques were used to calculate, for each of the 8 harvest intervals, dry matter production (DMP) and its components, net assimilation rate (NAR = rate of dry matter production per unit leaf area), and leaf area duration (LAD = total amount of leaf area present over time), according to the following formulas:

$$
\begin{aligned}
& \text { DMP }=W_{2}-W_{1} ; \\
& N A R=\left(W_{2} / A_{2}-W_{1} / A_{1}\right) \times[\alpha /(\alpha-1)] / T ; \text { and } \\
& \text { LAD }=\left[\left(A_{2}-A_{1}\right) /\left(\ln A_{2}-\ln A_{1}\right)\right] \times T
\end{aligned}
$$

where $W_{1}$ and $W_{2}=$ total plant dry weight $(g)$ at the beginning and end of a harvest interval, $A_{1}$ and $A_{2}=$ total leaf area at the beginning and end of the interval, $T=$ length of the harvest interval (days), and $\alpha=\left(\ln W_{2}-\ln W_{1}\right) /\left(\ln A_{2}-\ln A_{1}\right)$.

During a harvest interval, DMP $=$ NAR $\times$ LAD $($ Kvet et al. 1971). Correlation coefficients were calculated to evaluate the relationships between dry matter production and net assimilation rate or leaf area duration.

Data from the photoperiod experiment were subjected to analysis of variance with Duncan's multiple range test to determine effects of photoperiod on time to first appearance of flower buds and open flowers and their node position.

\section{Results and Discussion}

\section{Seed Germination}

Germination of acid-scarified seed of goatsrue was delayed slightly in the $26 / 14$ and $34 / 14^{\circ} \mathrm{C}$ regimes in comparison with the $26 / 22$ and $34 / 22^{\circ} \mathrm{C}$ regimes (Table 1). However, after 3 days, germination was $75 \%$ or greater, regardless of temperature. Thus,

Table 1. Effects of 4 temperature regimes on percent germination of seeds of goatsrue.

\begin{tabular}{lccc}
\hline \hline \multirow{2}{*}{$\begin{array}{l}\text { Day/night } \\
\text { temperature }\end{array}$} & \multicolumn{3}{c}{ Days after Planting } \\
\cline { 2 - 4 } & 1 & 2 & 3 \\
\hline$\left.{ }^{\circ} \mathrm{C}\right)$ & $53 \mathrm{~b}^{1}$ & $70 \mathrm{a}$ & $75 \mathrm{a}$ \\
$26 / 14$ & $68 \mathrm{a}$ & $76 \mathrm{a}$ & $81 \mathrm{a}$ \\
$26 / 22$ & $47 \mathrm{~b}$ & $72 \mathrm{a}$ & $76 \mathrm{a}$ \\
$34 / 14$ & $68 \mathrm{a}$ & $78 \mathrm{a}$ & $81 \mathrm{a}$ \\
$34 / 22$ & &
\end{tabular}

IWithin each column, values sharing the same letter are similar $(P>0.05)$.

over a range of 14 to $22^{\circ} \mathrm{C}$ night temperatures and 26 to $34^{\circ} \mathrm{C}$ day temperatures, high germination of seeds of goatsrue can be expected. This temperature range includes daily mean temperatures from 18 to $26^{\circ} \mathrm{C}$.

\section{Vegetative Growth}

After 89 days, the greatest total dry weight occurred at $26 / 22^{\circ} \mathrm{C}$ and the least (57\% of maximum) at $34 / 14^{\circ} \mathrm{C}$ (Table 2). Interme-

Table 2. Effects of 4 temperature regimes on vegetative growth of goatsrue at 89 days after emergence.

\begin{tabular}{lllll}
\hline \hline & \multicolumn{4}{c}{ Day/night temperature $\left(^{\circ} \mathrm{C}\right)$} \\
\cline { 2 - 5 } Variable & \multicolumn{1}{c}{$26 / 14$} & $26 / 22$ & $34 / 14$ & $34 / 22$ \\
\hline Total dry weight $(\mathrm{g})$ & $63.64 \mathrm{~b}^{1}$ & $72.25 \mathrm{a}$ & $41.23 \mathrm{c}$ & $62.07 \mathrm{~b}$ \\
Height $(\mathrm{cm})$ & $40.6 \mathrm{~b}$ & $48.9 \mathrm{a}$ & $34.3 \mathrm{~b}$ & $47.9 \mathrm{a}$ \\
Number of branches & $100.7 \mathrm{ab}$ & $113.0 \mathrm{ab}$ & $84.4 \mathrm{~b}$ & $128.3 \mathrm{a}$ \\
Number of leaves & $329 \mathrm{~b}$ & $463 \mathrm{a}$ & $275 \mathrm{~b}$ & $475 \mathrm{a}$ \\
Leaf area $\left(\mathrm{dm}^{2}\right)$ & $69.17 \mathrm{~b}$ & $86.65 \mathrm{a}$ & $50.13 \mathrm{c}$ & $77.27 \mathrm{ab}$ \\
\hline
\end{tabular}

${ }^{1}$ For each variable, values sharing the same letter are similar $(P>0.05)$.

diate values occurred at $26 / 14^{\circ} \mathrm{C}(88 \%)$ and $34 / 22^{\circ} \mathrm{C}(86 \%)$. The greatest plant heights were at $26 / 22^{\circ} \mathrm{C}$ and $34 / 22^{\circ} \mathrm{C}$, and the greatest numbers of branches were produced at $34 / 22^{\circ} \mathrm{C}$. In comparison with the $26 / 22^{\circ} \mathrm{C}$ regime, plants in the $34 / 14^{\circ} \mathrm{C}$ regime produced $41 \%$ fewer leaves and $42 \%$ less leaf area. These findings indicate that goatsrue is not well adapted to large diurnal variations in temperature. Such temperature conditions are typical of the Intermountain region where goatsrue currently is found. For example, the 30-year average daily maximum/minimum temperature during July at Logan, Ut., is $31 / 15^{\circ} \mathrm{C}$ (NOAA 1983). Growth of goatsrue is favored by intermediate temperatures with small 
diurnal variation. The mean daily temperatures were similar in the $26 / 22$ and $34 / 14^{\circ} \mathrm{C}$ regimes, but goatsrue exhibited markedly better growth at $26 / 22^{\circ} \mathrm{C}$. At a given day temperature, growth was greater with a $22^{\circ} \mathrm{C}$ night than with a $14^{\circ} \mathrm{C}$ night.

\section{Biomass and Leaf Area Partitioning}

As indicated by the leaf, stem, and root weight ratios calculated for the 89 day harvest, plants exposed to cool night temperatures $\left(26 / 14\right.$ and $\left.34 / 14^{\circ} \mathrm{C}\right)$ tended to partition more biomass into leaves and less into stems than did plants in the warmer night $\left(22^{\circ} \mathrm{C}\right)$ treatments (Table 3). Partitioning into roots was greatest at $26 / 14^{\circ}$ $\mathrm{C}$ and least at $34 / 22^{\circ} \mathrm{C}$. Distribution of leaf biomass as leaf area,

Table 3. Effects of 4 temperature regimes on biomass and leaf area partitioning in goatsrue 89 days after emergence.

\begin{tabular}{|c|c|c|c|c|}
\hline \multirow[b]{2}{*}{ Variable } & \multicolumn{4}{|c|}{ Day/night temperature $\left({ }^{\circ} \mathrm{C}\right)$} \\
\hline & $26 / 14$ & $26 / 22$ & $34 / 14$ & $34 / 22$ \\
\hline Leaf weight ratio $\left(\mathrm{g} \mathrm{g}^{-1}\right)$ & $0.381 \mathrm{a}^{1}$ & $0.337 b$ & $0.375 \mathrm{a}$ & $0.355 \mathrm{ab}$ \\
\hline Stem weight ratio $\left(\mathrm{g} \mathrm{g}^{-1}\right)$ & $0.284 c$ & $0.349 a$ & $0.312 b$ & $0.351 \mathrm{a}$ \\
\hline Root weight ratio $\left(\mathrm{g} \mathrm{g}^{-1}\right)$ & $0.336 \mathrm{a}$ & $0.314 \mathrm{a}$ & $0.313 \mathrm{ab}$ & $0.295 b$ \\
\hline Specific leaf area $\left(\mathrm{dm}^{2} \mathrm{~g}^{-1}\right)$ & $2.90 \mathrm{~b}$ & $3.59 \mathrm{a}$ & $3.28 \mathrm{ab}$ & $3.52 \mathrm{a}$ \\
\hline Leaf area ratio $\left(\mathrm{dm}^{2} \mathrm{~g}^{-1}\right)$ & $1.10 \mathrm{a}$ & $1.21 \mathrm{a}$ & $1.23 \mathrm{a}$ & $1.25 \mathrm{a}$ \\
\hline
\end{tabular}

'For each variable, values sharing the same letter are similar $(P>0.05)$.

indicated by the values for specific leaf area (SLA), was least at $26 / 14^{\circ} \mathrm{C}$ and did not differ significantly among the other 3 temperature regimes. The leaf area ratio, which is the product of the leaf weight ratio and the specific leaf area (Kvet et al. 1971), did not vary significantly within the temperature range studied. This occurred because of compensating shifts in the 2 components of leaf area ratio. Those temperature regimes yielding a high leaf weight ratio $\left(26 / 14\right.$ and $\left.34 / 14^{\circ} \mathrm{C}\right)$ tended to have a lower specific leaf area, whereas those regimes with lower leaf weight ratio values yielded higher specific leaf area. The trends in biomass partitioning and leaf area distribution noted above for the 89-day-old plants were identical to those reflected in allometric coefficients calculated from data collected over the entire growth period (Table 4). Thus, it appears that biomass allocation patterns may be set early during vegetative growth, at least when growth conditions are constant.

\section{Dry Matter Production and Components}

The relationship, DMP $=$ NAR $\times$ LAD provides a means of assessing the relative importance of variation in photosynthetic rate (NAR) and leaf area factors (LAD) in accounting for treatment-induced differences in dry matter accumulation. In goatsrue, trends in dry matter production over time were similar to trends in leaf area duration (Fig. 1). While dry matter production and leaf area duration increased with time, net assimilation rate decreased. Correlation analysis confirmed the close relationship between dry matter production and leaf area duration (Table 5). When all temperatures and harvest intervals were included, varia-
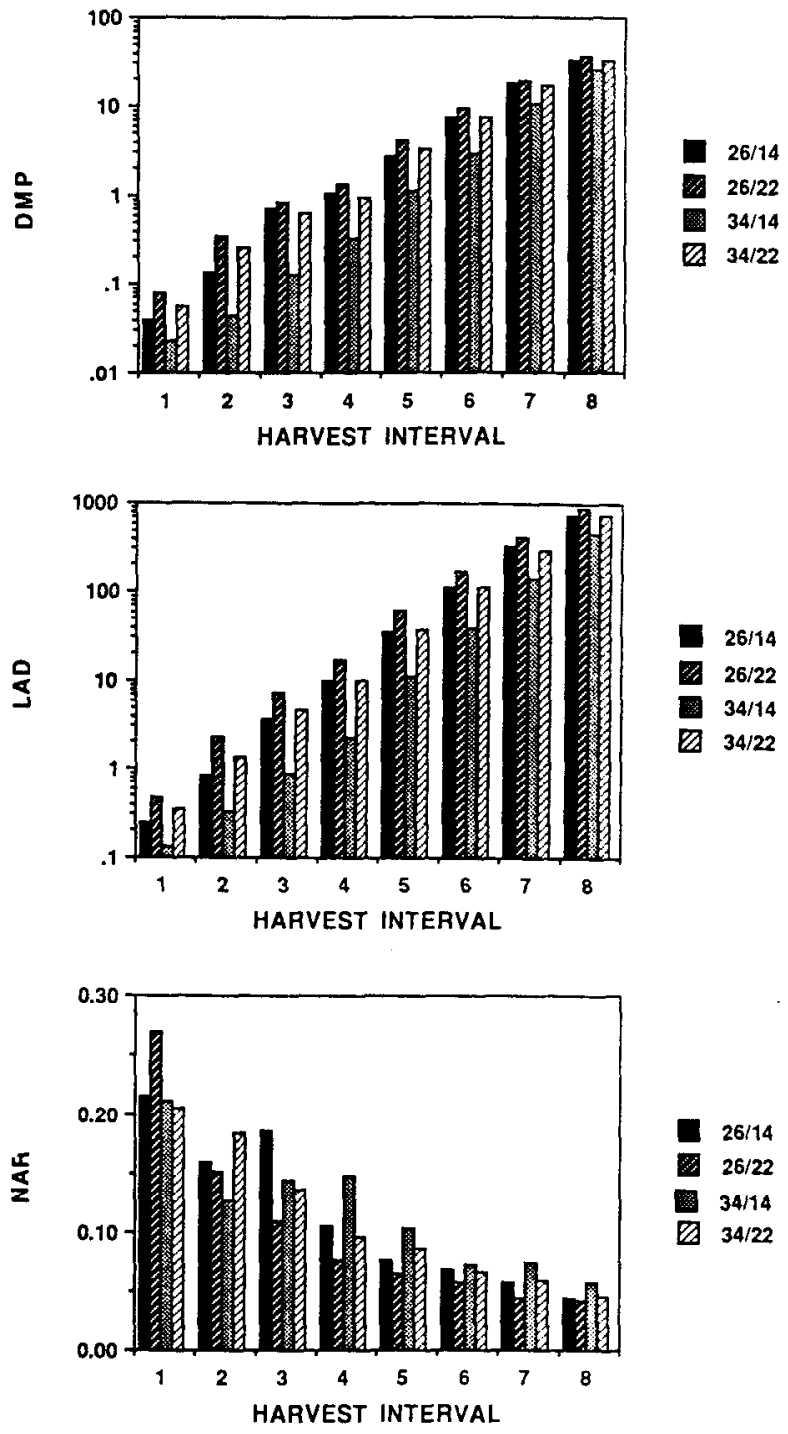

Fig. 1. Effects of day/night temperature on dry matter production (DMP), leaf area duration $(L A D)$ and net assimilation rate $(N A R)$ of goatsrue. $D M P$ and $L A D$ are plotted on a logarithmic scale so that small values early in the growth period are discernible.

tion in leaf area duration could account for $95 \%$ of the variation in dry matter production, $\left(R^{2}=0.952\right)$. Variation in net assimilation rate could account for only $35 \%$ of the variation in dry matter production $\left(R^{2}=0.346\right)$. Within individual temperature regimes, variation in leaf area duration accounted for 94 to $98 \%$ of the variation in dry matter production. By comparison, variation in net assimilation rate within temperature regimes over time could

Table 4. Allometric coefficients calculated from multiple harvests of goatsrue grown in 4 temperature regimes from 14 to 89 days after emergence.

\begin{tabular}{|c|c|c|c|c|c|}
\hline \multicolumn{2}{|c|}{ Variable } & \multicolumn{4}{|c|}{ Day/night temperature $\left({ }^{\circ} \mathrm{C}\right)$} \\
\hline $\mathrm{Y}$ & $\mathrm{X}$ & $26 / 14$ & 26.22 & $34 / 14$ & $34 / 22$ \\
\hline Leaf wt & Total wt & $0.382^{1}(0.005)^{2}$ & $0.330(0.004)$ & $0.369(0.003)$ & $0.348(0.003)$ \\
\hline Stem wt & Total wt & $0.281(0.003)$ & $0.350(0.004)$ & $0.313(0.004)$ & $0.346(0.005)$ \\
\hline Root wt & Total wt & $0.337(0.005)$ & $0.320(0.006)$ & $0.319(0.004)$ & $0.306(0.007)$ \\
\hline Leaf area & Leaf wt & $2.79(0.07)$ & $3.58(0.06)$ & $3.26(0.03)$ & $3.48(0.06)$ \\
\hline Leaf area & Total wt & $1.08(0.02)$ & $1.18(0.03)$ & $1.20(0.02)$ & $1.20(0.03)$ \\
\hline
\end{tabular}

ICoefficients are from regression equations of the form $y=m x+b$

${ }^{2}$ Values in parentheses are standard errors of regression coefficients $(m)$. 
Table 5. Correlations between dry matter production (DMP) and its components, net assimilation rate (NAR) and leaf area duration (LAD) in goatsrue grown for 89 days in 4 temperature regimes.

\begin{tabular}{|c|c|c|c|c|}
\hline Population & $Y$ & $\mathbf{X}$ & $R^{2}$ & $\begin{array}{l}\text { Level of } \\
\text { significance }\end{array}$ \\
\hline \multirow{2}{*}{ All } & DMP & NAR & 0.346 & 0.0001 \\
\hline & DMP & LAD & 0.952 & 0.0001 \\
\hline \multicolumn{5}{|c|}{$\begin{array}{l}\text { Day/night } \\
\text { temperature }\left({ }^{\circ} \mathrm{C}\right)\end{array}$} \\
\hline $26 / 14$ & $\begin{array}{l}\text { DMP } \\
\text { DMP }\end{array}$ & $\begin{array}{l}\text { NAR } \\
\text { LAD }\end{array}$ & $\begin{array}{l}0.471 \\
0.961\end{array}$ & $\begin{array}{l}0.0001 \\
0.0001\end{array}$ \\
\hline $26 / 22$ & $\begin{array}{l}\text { DMP } \\
\text { DMP }\end{array}$ & $\begin{array}{l}\text { NAR } \\
\text { LAD }\end{array}$ & $\begin{array}{l}0.284 \\
0.972\end{array}$ & $\begin{array}{l}0.0001 \\
0.0001\end{array}$ \\
\hline $34 / 14$ & $\begin{array}{l}\text { DMP } \\
\text { DMP }\end{array}$ & $\begin{array}{l}\text { NAR } \\
\text { LAD }\end{array}$ & $\begin{array}{l}0.351 \\
0.984\end{array}$ & $\begin{array}{l}0.0001 \\
0.0001\end{array}$ \\
\hline $34 / 22$ & $\begin{array}{l}\text { DMP } \\
\text { DMP }\end{array}$ & $\begin{array}{l}\text { NAR } \\
\text { LAD }\end{array}$ & $\begin{array}{l}0.306 \\
0.940\end{array}$ & $\begin{array}{l}0.0001 \\
0.0001\end{array}$ \\
\hline \multicolumn{5}{|l|}{$\begin{array}{l}\text { Harvest } \\
\text { interval }\end{array}$} \\
\hline 1 & DMP & $\begin{array}{l}\text { NAR } \\
\text { LAD }\end{array}$ & $\begin{array}{l}0.458 \\
0.976\end{array}$ & $\begin{array}{l}0.0001 \\
0.0001\end{array}$ \\
\hline 2 & DMP & $\begin{array}{l}\text { NAR } \\
\text { LAD }\end{array}$ & $\begin{array}{l}0.226 \\
0.942\end{array}$ & $\begin{array}{l}0.0107 \\
0.0001\end{array}$ \\
\hline 3 & DMP & $\begin{array}{l}\text { NAR } \\
\text { LAD }\end{array}$ & $\begin{array}{l}0.008 \\
0.767\end{array}$ & $\begin{array}{l}0.6548 \\
0.0001\end{array}$ \\
\hline 4 & DMP & $\begin{array}{l}\text { NAR } \\
\text { LAD }\end{array}$ & $\begin{array}{l}0.063 \\
0.760\end{array}$ & $\begin{array}{l}0.1976 \\
0.0001\end{array}$ \\
\hline 5 & DMP & $\begin{array}{l}\text { NAR } \\
\text { LAD }\end{array}$ & $\begin{array}{l}0.408 \\
0.894\end{array}$ & $\begin{array}{l}0.0003 \\
0.0001\end{array}$ \\
\hline 6 & DMP & $\begin{array}{l}\text { NAR } \\
\text { LAD }\end{array}$ & $\begin{array}{l}0.137 \\
0.912\end{array}$ & $\begin{array}{l}0.0524 \\
0.0001\end{array}$ \\
\hline 7 & DMP & $\begin{array}{l}\text { NAR } \\
\text { LAD }\end{array}$ & $\begin{array}{l}0.012 \\
0.574\end{array}$ & $\begin{array}{l}0.5762 \\
0.0001\end{array}$ \\
\hline 8 & DMP & $\begin{array}{l}\text { NAR } \\
\text { LAD }\end{array}$ & $\begin{array}{l}0.187 \\
0.613\end{array}$ & $\begin{array}{l}0.0216 \\
0.0001\end{array}$ \\
\hline
\end{tabular}

account for only 28 to $47 \%$ of the variation in dry matter production. Variation in dry matter production over temperature within each harvest interval also was more closely correlated with leaf area duration than with net assimilation rate. However, correlation of dry matter production with either leaf area duration or net assimilation rate tended to decline with plant age.

\section{Effects of Temperature and Subsequent Photoperiod on Repro- ductive Development}

Analysis of variance revealed highly significant effects of photoperiod on reproductive development (Table 6). Increasing the photoperiod from 14 to 16 or 18 hours greatly reduced the time required for the first appearance of flower buds or flowers. Flower buds appeared at lower nodes on plants in the longer photoperiods. Temperature during early growth affected the node position of first bud appearance but generally not the time to bud or flower appearance. An exception was the $34 / 14^{\circ} \mathrm{C}$ regime, which was least favorable to vegetative growth. Bud and flower appearance were delayed in plants taken from this regime, which is most typical of summer conditions where goatsrue currently occurs.

These results from the photoperiod study indicate that long days stimulate reproductive development in goatsrue. No reproductive development occurred in a 12-hour photoperiod after 130 days. The threshold photoperiod for rapid reproductive development apparently lies between 14 and 16 hours.

Implications for Potential Geographic Range and Impact of Goatsrue in the United States

Since its introduction into northern Utah 100 years ago, goatsrue has remained confined to a relatively small geographical
Table 6. Effects of photoperiod, and temperature during early growth, on reproductive development of goatsrue.

\begin{tabular}{lcccc}
\hline \hline Photoperiod & $\begin{array}{c}\text { Day/night } \\
\text { temperature }\end{array}$ & $\begin{array}{l}\text { Time to } \\
\text { bud }^{3}\end{array}$ & $\begin{array}{l}\text { Time to } \\
\text { flower }\end{array}$ & $\begin{array}{l}\text { Node position } \\
\text { of first bud }\end{array}$ \\
\hline (hours) & $\left({ }^{\circ} \mathrm{C}\right.$ ) & $\begin{array}{l}\text { (days) } \\
\text { (days) }\end{array}$ & \\
& $26 / 14$ & 68.2 & 74.8 & 25.6 \\
& $26 / 22$ & 68.9 & 75.0 & 26.1 \\
& $34 / 14$ & 80.0 & 85.0 & 24.3 \\
mean $^{4}$ & $34 / 22$ & 65.8 & 89.8 & 27.8 \\
16 & & $69 \mathrm{a}$ & $80 \mathrm{a}$ & $26 \mathrm{a}$ \\
& $26 / 14$ & 24.6 & 33.9 & 14.3 \\
& $26 / 22$ & 23.9 & 33.7 & 15.0 \\
& $34 / 14$ & 30.4 & 40.4 & 15.8 \\
mean $^{4}$ & $34 / 22$ & 25.1 & 34.7 & 15.9 \\
18 & & $26 \mathrm{~b}$ & $36 \mathrm{~b}$ & $15 \mathrm{~b}$ \\
& $26 / 14$ & 18.9 & 27.3 & 12.4 \\
& $26 / 22$ & 19.1 & 27.3 & 13.8 \\
& $34 / 14$ & 22.7 & 31.5 & 14.0 \\
mean $^{4}$ & $34 / 22$ & 19.5 & 28.2 & 13.6 \\
\hline
\end{tabular}

1,20-day-old plants were transferred from 12-hour photoperiods at the 4 day/night temperatures to 4 photoperiod chambers all having a $26 / 22^{\circ} \mathrm{C}$ day/night temperature. ${ }^{3}$ Time in days after transfer to the photoperiod chambers for appearance of first flower bud or first open flower.

4Mean values include all temperatures within each photoperiod treatment. Within each column, mean values sharing the same letter are not significantly different at the 0.05 level.

area of some $155 \mathrm{~km}^{2}$. Based on its response to temperature demonstrated in the present study, it is apparent that goatsrue is not well-adapted to large diurnal variations in temperature. Its growth is favored by mild temperatures with small diurnal variations.

Large diurnal variations in temperature are typical of growing season conditions in the area of the U.S. where goatsrue currently occurs. For example, the average diurnal variation (maximum-minimum temperature) during the months of April through October at Logan, Ut., is $14.3^{\circ} \mathrm{C}$ (NOAA 1983). The average daily maximum/minimum temperatures for each month during this period are: April: $14 / 2^{\circ} \mathrm{C}$; May: $20 / 7^{\circ} \mathrm{C}$; June: $25 / 11^{\circ} \mathrm{C}$; July: $31 / 15^{\circ} \mathrm{C}$; August: $30 / 14^{\circ} \mathrm{C}$; September: $24 / 9^{\circ} \mathrm{C}$; and October: $17 / 4^{\circ} \mathrm{C}$. Conditions to the north and west of the Logan area are more extreme. Therefore, further expansion of goatsrue from its current site of infestation may have been limited by climatic conditions in its immediate and surrounding area. The generally arid conditions of the Intermountain West also likely have limited the natural establishment of goatsrue outside the Cache Valley, where it is largely restricted to areas of high soil moisture such as ditchbanks, irrigated pastures and alfalfa fields, and natural seepage areas (Tingey 1971, Evans 1984).

Because its growth is favored by temperatures different from those typical of its current range, goatsrue may have considerable unrealized potential as a pest over a wide geographical range in the U.S. Its native and naturalized distribution in both the Old and New World also indicate that goatsrue is unlikely to remain confined to the current area of infestation. That it apparently has been so confined to date is testimony to the effectiveness of the control and eradication program directed at it by USDA/APHIS and the state of Utah.

The seed of goatsrue are not wind-dispersed but readily float and are spread by flowing water in streams or irrigation systems. It is not known whether the seeds are dispersed by birds or mammals. These restrictions on seed dispersal and the requirement for moist soil clearly limit the potential for the rapid spread of goatsrue outside the currently infested area. However, movement of seed on farm equipment or farm commodities or by flowing water could introduce goatsrue into areas favorable for its growth. Should goatsrue become established in a more favorable area, outside its 
current range, its further spread clearly would not be greatly limited by its temperature and photoperiod requirements for vegetative growth and reproductive development. Temperature and moisture conditions in the midwestern and southeastern U.S. probably would support rapid establishment and growth of goatsrue. Therefore, the further spread of goatsrue must be curtailed. The fortuitous combination of natural dispersal barriers and a limited current infestation make this weed a reasonable and opportune target for containment and eventual eradication.

\section{Literature Cited}

Barneby, R.C. 1989. Fabales, p. 186-187. In: A. Cronquist, A.H. Holmgren, N.H. Holmgren, J.L. Reveal, and P.K. Holmgren (eds.) Intermountain flora. Vascular plants of the Intermountain West, U.S.A. Vol. 3. New York Botanical Garden, Bronx, N.Y.

Barnes, D.K., E.T. Bingham, J.D. Axtell, and W.H. Davis. 1972. The flower, sterility mechanisms, and pollination controls, p. 123-142. In. C.H. Hanson (ed.) Alfalfa science and technology. Amer. Soc. of Agron., Madison, Wis.

Downs, R.J., and H. Hellmers. 1975. p. $112 \mathrm{In}$ : Environment and the experimental control of plant growth. Academic Press, N.Y.

Evans, J.0. 1984. Goatsrue eradication. A realistic goal. Utah Sci. 45:8-11.
Evans, J.0., and M.L. Ashcroft. 1982. Goatsrue. Res. Rep. 79. Utah Agr. Exp. Sta., Utah State Univ., Logan.

Holm, L., J.W. Pancho, J.P. Herberger, and D.L. Plucknett. 1979. A geographical atlas of world weeds. John Wiley \& Sons. N.Y.

Kvet, J., J.P. Ondok, J. Necas, and P.G. Jarvis. 1971. Methods of growth analysis. p. 343-391. In: Z. Sestak, J. Catsky, and P.G. Jarvis (eds.) Plant photosynthetic production. Manual of Methods. W. Junk, The Hague. NOAA. 1983. Climate normals for the U.S. (Base: 1951-1980), p. 619-632. Gale Research Co., Detroit.

Patterson, D.T. 1983. Research on exotic weeds, p. 381-393. In: C.L. Wilson and C.L. Graham (eds.) Exotic plant pests and North American Agriculture. Academic, N.Y.

Tingey, D.C. 1971. Goatsrue, a potential forage crop, turned out to be a weed. Utah Sci. 32:25-28.

Tutin, T.G., V.H. Heywood, N.A. Burges, D.M. Moore, D.H. Valentine, S.M. Walters, and D.A. Webb. 1976. Flora Europaea. Cambridge Univ. Press, Cambridge.

Westbrooks, R.G. 1989. Regulatory exclusion of Federal Noxious Weeds from the United States. Ph.D. Thesis, North Carolina State Univ., Raleigh, N.C.

Williams, M.C. 1980. Purposefully introduced plants that have become noxious or poisonous weeds. Weed Sci. 28:300-305.

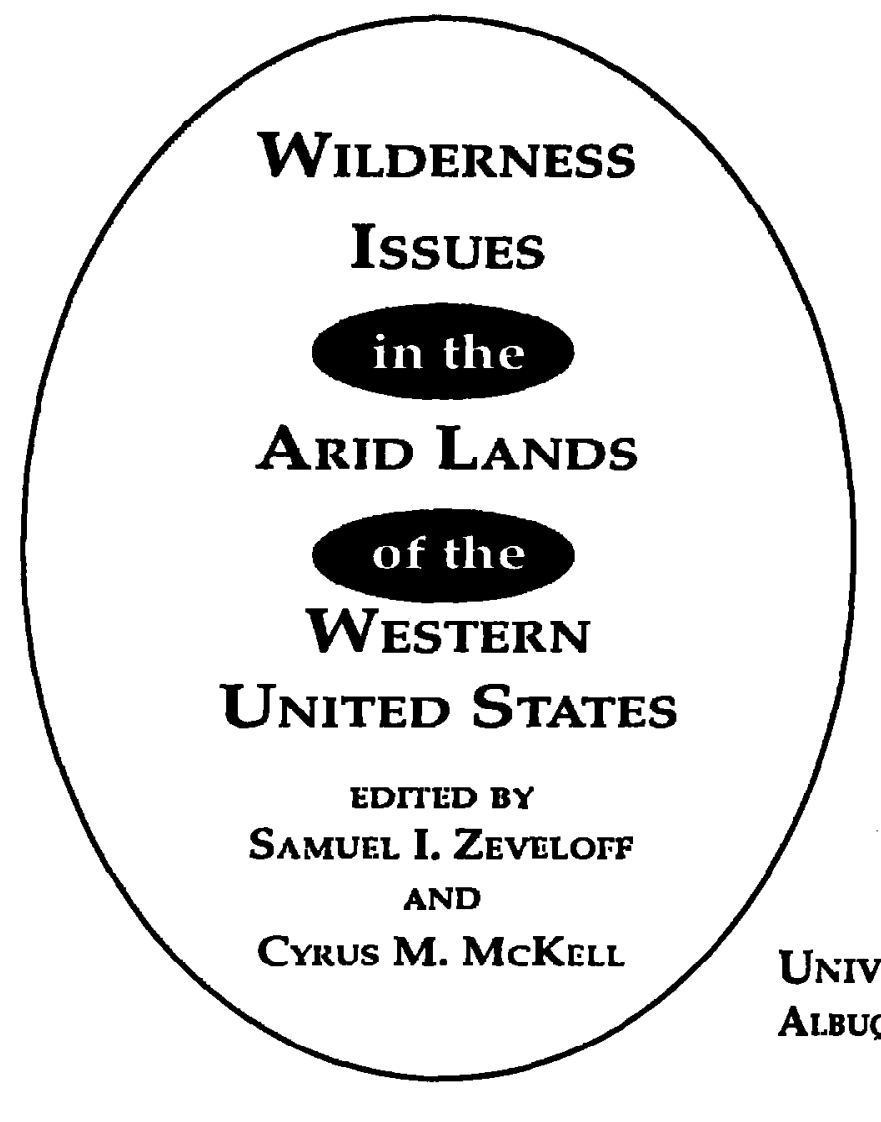

America is running out of new lands that can be set aside as wilderness-this book addresses issues involved in designating arid lands as wilderness. The basic question raised is whether this nation, and the West, will protect and enhance wilderness areas and unique aquatic habitats, or let them and their rare and endangered species of plants and animals follow others into possible extinction.

Cloth: 0-8263-1365-5 \$29.95

At bookstores, or call

(505) $277-4810$

FAX 1-800-622-8667

University of New Mexico Press Albuquerque, NeW MeXco 87131-1591

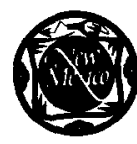

